Innlegg på inntil 400 ord lastes opp i http://mc.manuscriptcentral.com/tidsskriftet.

Redaksjonen forbeholder seg retten til å foreta redaksjonelle endringer.

Forfattere av vitenskapelige artikler har automatisk tilsvarsrett (jf. Vancouver-gruppens regler).

\section{Kynisme og profittjag}

Yngve Mikkelsen, Trond Methi og Monica Kjeken forsvarer legemiddelindustrien i Tidsskriftet nr. 13-14/2010 (1-3). De tre innleggene gjelder Robin Holtedahls artikkel om pregabalin ved fibromyalgi (4) og min leder om det samme tema (5). I motsetning til Holtedahl fikk jeg - til tross for at jeg innstendig ba redaksjonen i Tidsskriftet om det - ikke besvare innleggene i samme nummer. Det liker jeg dårlig.

Sist jeg diskuterte publiseringsetikk med Pfizer et al, var tema en legemiddelgruppe som for ettertiden vil være knyttet til den kanskje største sikkerhetsskandalen noensinne - de selektive COX-2-hemmerne (6). Det ser dessverre ut til at industrien har lært lite av den tildragelsen, der i gården er det tydeligvis «business as usual».

Mange av oss som arbeider med legemidler i universitets- og sykehussektoren, opplever ikke alltid farmasøytisk industri som en profesjonell samarbeidspartner med høy etisk standard, og uroes i tiltakende grad av industriens kynisme og ensidige profittjag. Innleggene fra Mikkelsen (1) og Kjeken (3) befester dette inntrykket. Legemiddelutvikling gjøres nå nesten utelukkende i industriregi. Det er imidlertid langt mellom de innovative produktene - «me too»-midler og kliniske studier innrettet mot placebosammenlikninger og «noninferiority»-mål dominerer, og interessekonfliktene florerer. Pregabalin eksemplifiserer alt dette. Da blir spørsmålet om antall pregabalinstudier og hvor mange av disse Pfizer har unnlatt å publisere (1) ikke det sentrale.

Yngve Mikkelsen skal på tampen få litt nødvendig voksenopplæring: De godkjente norske indikasjonene for pregabalin er korrekt referert i min leder (5). Cochrane-analysen (7) - hvor første- og sisteforfatteren forresten har mottatt pengestøtte fra legemiddelindustrien, inklusive Pfizer (8) viser at pregabalin både er lite effektivt og gir uttalte bivirkninger. EULAR baserer sine terapianbefalinger ved fibromyalgi på en konsensusuttalelse fra et såkalt ekspertpanel hvor det nærmest flommer over av industribindinger - med Pfizer på fremtredende plass (9). Det kan i den forbindelse nevnes at en tilsvarende EULAR-utredning for få år tilbake anbefalte COX-2-hemmere omtrent samtidig med at flere av dem ble trukket fra markedet (10). Det er ellers bred enighet om at ekspertvurderinger skal graderes lavt med hensyn til evidensnivå (11).
At et middel har misbrukspotensial, betyr at det kan misbrukes (12).

\section{Lars Slørdal}

Norges teknisk-naturvitenskapelige universitet/ St. Olavs hospital

\section{Litteratur}

1. Mikkelsen Y. Uetterettelig om legemiddelindustrien. Tidsskr Nor Legeforen 2010; 130: 1331.

2. Methi T. Legemiddelindustriens troverdighet. Tidsskr Nor Legeforen 2010; 130: 1330.

3. Kjeken M. Man kan stole på legemiddelindustrien. Tidsskr Nor Legeforen 2010; 130: 1330.

4. Holtedahl R. Tvilsom dokumentasjon av effekten av pregabalin ved fibromyalgi. Tidsskr Nor Legeforen 2010; 130: 1032-6.

5. Slørdal L. Kan vi stole på legemiddelindustrien? Tidsskr Nor Lægeforen 2010; 130: 1013.

6. Slørdal L. Skandaleoppslag om COX-2-hemmer Tidsskr Nor Lægeforen 2002; 122: 1708-9.

7. Moore RA, Straube S, Wiffen PJ et al. Pregabalin for acute and chronic pain in adults. Cochrane Database Syst Rev 2009; nr. 3: CD007076.

8. www.medicine.ox.ac.uk/bandolier/aboutus.html (15.6.2010).

9. Carville SF, Arendt-Nielsen S, Bliddal $\mathrm{H}$ et al. EULAR evidence-based recommendations for the management of fibromyalgia syndrome. Ann Rheum Dis 2008; 67: 536-41.

10. Bjordal JM, Ljunggren AE, Klovning A et al. NSAIDs, including coxibs, probably do more harm than good, and paracetamol is ineffective for hip OA. Ann Rheum Dis 2005; 64: 655-6.

11. Bjordal JM, Klovning A, Slørdal L. Evaluering av medisinsk behandling: hva vet vi, og hvordan bør kunnskapet håndteres? Nor J Epidemiol 2008; 18 : $136-46$

12. Bramness JG, Sandvik P, Engeland A et al. Does pregabalin (Lyrica) help patients reduce their use of benzodiazepines? A comparison with gabapentin using the Norwegian prescription database. Basic Clin Pharmacol Toxicol 2010; e-publisert 23. april.

\section{Begrenset behandling av dyre premature?}

I Tidsskriftet nr. 11/2010 beskriver Dag Bratlid \& Anja Nordermoen utviklingen av og kostnadene ved prematurbehandling i Norge de siste tiårene $(1,2)$. Nyfødte med fødselsvekt $<1000 \mathrm{~g}$ sies å være «den dyreste pasientgruppen av noe størrelse som behandles ved norske sykehus» (2). I en redaksjonell kommentar (3) hevder Dag Helge Frøisland at vi bør begrense behandlingen av disse.

I 2007 kostet behandlingen av en ekstremt prematur ved St. Olavs hospital drøyt 900000 kroner (2). Frøisland hevder at «for dem som er født etter 23 og 24 uker er det lav overlevelse» (3). I den norske prematurkohorten fra slutten av 1990-årene overlevde hhv. $39 \%$ og $60 \%$ av dem som ble født etter hhv. 23 og 24 ukers svangerskap (4). For hvilke andre pasienter med en ellers dødelig sykdom vil en overlevelse på $40-60 \%$ bli karakterisert som «lav»?

Etter pasientrettighetsloven har premature samme rett til behandling som andre. Hvis «lav overlevelse» er et argument for ikke å behandle disse, må det også kunne appliseres på andre pasientgrupper. Pasienter med pancreaskreft, som har en overlevelse på hhv. ca. $20 \%$ og $10 \%$ etter hhv. ett og fem år, bør kanskje ikke tilbys behandling? Utgiftene til avansert kreftbehandling kan komme opp i flere hundre tusen kroner i året. Skal vi slutte med dette?

Nyfødtintensivmedisinen hevdes å være noe av det mest kostnadseffektive som tilbys av avansert medisin (5). Amortisert over et livsløp blir kostnadene per kvalitetsjustert leveår (QUALY) for en prematur ganske beskjedne. $90 \%$ av utgiftene i en nyfødtintensivenhet brukes på dem som utskrives levende. De som dør, dør etter kort tid, mens overleverne ligger lenge. Tallene fra St. Olavs hospital bekrefter dette (1). Innen voksenintensivmedisinen er forholdet motsatt, i hvert fall i USA - de som blir friske, skrives ut raskt, og de som dør, ligger lenge (6) og koster mye (7).

Noen av dem som overlever ekstrem prematuritet betaler en pris i form av nedsatt funksjonsevne. Likevel synes de at livet har kvaliteter og verdi (8). Kanskje vi bør slutte med å diskriminere premature i Norge?

\section{Thor Willy Ruud Hansen}

Oslo

\section{Litteratur}

1. Bratlid D, Nordermoen A. Behandlingen av svært for tidlig fødte barn de siste 40 år. Tidsskr Nor Legeforen 2010: 130: 1127-9.

2. Nordermoen A, Bratlid D. Kostnader ved behandling av svært for tidlig fødte barn. Tidsskr Nor Legeforen 2010; 130: 1130-4.

3. Frøisland DH. Behandlingsgrenser for esktremt premature. Tidsskr Nor Legeforen 2010; 130: 1120

4. Markestad T, Kaaresen PI, Rønnestad A et al. Early death, morbidity, and need of treatment among extremely premature infants. Pediatrics 2005; 115 1289-98.

5. Meadow W, Lantos J. Moral reflections on neonatal intensive care. Pediatrics 2009; 123: 595-7.

6. Levine SK, Sachs GA, Jin L et al. A prognostic model for 1-year mortality in older adults after hospital discharge. Am J Med 2007; 120: 455-60.

7. Lantos JD, Mokalla M, Meadow W. Resource allocation in neonatal and medical ICUs: epidemiology and rationing at the extremes of life. Am J Resp Crit Care Med 1997; 156: 185-9.

8. Saigal S, Stoskopf BL, Feeny D et al. Differences in preferences for neonatal outcomes among health care professionals, parents, and adolescents. JAMA 1999; 281: 1991-7. 